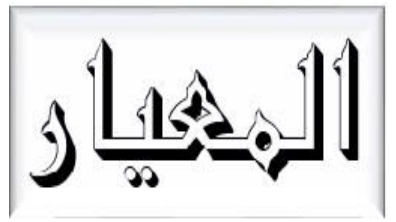

Al Mi'yar

Vol. 4, No. 2, Oktober 2021

P-ISSN: 2620-6749, E-ISSN: 2620-6536

DOI: $10.35931 / a m . v 4 i 2.530$

Naskah diterima: 24-02-2021

Direvisi: 29-03-2021

Disetujui: 15-10-2021

\title{
Perifrasa dalam Retorika Presiden Mahmoud Abbas (Studi Balaghah Perspektif Politik)
}

\author{
Muhammad Bachrul Ulum \\ UIN Sunan Kalijaga, Yogyakarta, Indonesia \\ Email: Ulumbangsal@gmail.com
}

\begin{abstract}
The strategy in rhetoric is a crucial ability that politicians must possess so that what is conveyed can be accepted by the public entirely and widely. This study will discuss how Palestinian President Mahmoud Abbas devised a rhetorical strategy using Periphrases in his Speech at the 75th United Nations General Assembly to transfer his political message to the world. Precisely a few days after the announcement of the agreement to normalize diplomatic relations of the United Arab Emirates (UAE) and Bahrain with Israel. Mahmoud Abbas is an accomplished diplomat who has succeeded in bringing Palestine to progressive achievements to gain recognition of sovereignty and political support from other countries. This study uses a qualitative method with a literature study model. The data collection method used the listening method with the free-talk listening technique (SBC) and the note-taking technique as an advanced method. The results of this study are that Mahmoud Abbas pours many political messages in the phrases he used when delivering the Speech, which was stated through Ithnab's functions based on social facts in Palestine.
\end{abstract}

Keywords : Periphrase, rhetoric, politic, Mahmoud Abbas, Palestine 
Muhammad Bachrul Ulum: Perifrasa dalam Retorika Presiden Mahmoud Abbas (Studi Balaghah Perspektif Politik)

\section{Pendahuluan}

Dalam beberapa kasusnya, karya sastra, pidato kenegaraan, orasi dan produk - produk bahasa lainnya dapat membangkitkan people power yang begitu besar. Di Indonesia kita kenal Bung Tomo asal Surabaya yang selalu berapi - api dalam setiap orasinya. Strategi retorika Bung Tomo adalah interteks keagamaan, semangat yang meledak-ledak saat memekikkan takbir "Allahu Akbar.. Merdeka atau mati !" menggetarkan hati dan mengobarkan semangat jiwa perjuangan arek-arek suroboyo dalam melawan penajajahan Belanda. Dalam sejarah sastra Arab, dikenal istilah Puisi Perlawanan (Al-Adab Al-Muqawamah) yang muncul akibat keresahan masyarakat Palestina atas penderitaan yang mereka alami meskipun tak hentinya melakukan perlawanan ${ }^{1}$, baik secara diplomatis maupun militer. Diantara tokoh puisi perlawanan yang mendunia adalah Mahmoud Darwish. Beliau sampai pernah ditangkap militer Israel tahun 1965 karena sebuah pementasan puisi di Al-Quds University. Puisinya dianggap sebagai ancaman bagi dunia politik IsraelPalestina.

Hal - hal diatas menunjukkan bahwa Ilmu kebahasaan sangat berjasa terhadap para politikus, bagaimana tidak? Dengan adanya ilmu soal retorika, politikus dapat menyusun strategi untuk meyakinkan para pendukungnya terhadap validitas argumennya dengan penggunaan bahasa yang halus dan persuasif ${ }^{2}$. Bahasa menjadi media yang ampuh untuk menanamkan ideologi,

${ }^{1}$ Ghulam Falach dan Ridhatullah Assya'bani, "TELAAH SEMIOTIK PENDIDIKAN NASIONALISME DALAM PUISI 'RISĀLAH MIN AL MU'TAQIL' KARYA SĀMIH ALQĀSIM," Al Mi'yar: Jurnal Ilmiah Pembelajaran Bahasa Arab Dan Kebahasaaraban 3, no. 2 (10 Oktober 2020): 232, https://doi.org/10.35931/am.v3i2.341. 2004), 39.

${ }^{2}$ Linda Thomas dkk., Language, society and power: An introduction (Psychology Press, 
Muhammad Bachrul Ulum: Perifrasa dalam Retorika Presiden Mahmoud Abbas (Studi Balaghah Perspektif Politik)

merebut, mendapatkan, dan mempertahankan kekuasaan ${ }^{3}$ Penggunaan bahasa yang tepat dapat mempengaruhi pendirian seseorang, karena pada dasarnya statement politik adalah transfer ideologi, yang bermula dari proses enkode dari otak politikus, ditranfer dan diproses secara dekode oleh otak para pendukung. Menyampaikan maksud politik melalui bahasa mempunyai media yang beragam. Bisa lewat karya sastra, pidato, orasi, kampanye, konferensi pers, dsb. retorika merupakan sentral bagi politik, kendati kita tau politik adalah bentuk lain dari peperangan ${ }^{4}$.

Pidato merupakan bentuk penggalangan kekuasaan melalui media dengan memanfaatkan fitur - fitur linguistik ${ }^{5}$. Pidato adalah hal yang sangat krusial bagi pejabat politik, karena pemahaman masyarakat mengenai suatu pemerintahan tak luput dari kegiatan komunikatif yang dilakukan oleh beliau' ${ }^{6}$. Maka menyusun pidato yang benar sampai ke detail - detailnya adalah sebuah keharusan bagi seorang pejabat politik. Salah satu komponen yang harus dipertimbankgkan oleh seorang pejabat politik dalam menulis sebuah pidato adalah retorika.

Retorika berasal dari bahasa Yunani yang berarti seni berbicara. Pada perkembangannya retorika kini digunakan dalam komunikasi 1 arah, antara 1 orang penutur dan lebih dari satu mitra tutur atau dikenal dengan istilah seni

3 Abdul Ghoni Asror, "Bahasa pencitraan dalam iklan kampanye pilkada kabupaten Bojonegoro," Magistra 26, no. 92 (2015): 48.

${ }^{4}$ Ronald R. Krebs dan Patrick Thaddeus Jackson, "Twisting Tongues and Twisting Arms: The Power of Political Rhetoric," European Journal of International Relations 13, no. 1 (1 Maret 2007): 36, https://doi.org/10.1177/1354066107074284.

${ }^{5}$ Rangga Asmara, "Strategi Kebahasaan Presiden Jokowi Dalam Menanamkan Ideologi Dan Manifesto Pemerintahan,” Litera 15, no. 2 (2016): 380, https://doi.org/10.21831/ltr.v15i2.11836.

${ }^{6}$ Marsefio S. Luhukay, "Presiden SBY dan Politik Pencitraan: Analisis Teks Pidato Presiden SBY dengan Pendekatan Retorika Aristoteles,” Scriptura 1, no. 2 (2007): 52. 
Muhammad Bachrul Ulum: Perifrasa dalam Retorika Presiden Mahmoud Abbas (Studi Balaghah Perspektif Politik)

Public Speaking7. Dalam bahasa Arab, Ilmu Retorika adalah ilmu yang membahas tentang Fashahat Al-Kalam (kefasihan berbicara). kriteria ucapan yang retoris dalam bahasa Arab adalah Memiliki makna yang jelas, pelafalan yang mudah, serta format morfologis yang baik ${ }^{8}$ Bahasa Arab adalah satu satunya bahasa yang memiliki teori retorika yang cukup kompleks, mulai dari retorika kulit luar sebuah wacana, baik dari kontruksi kata maupun kontruksi makna yang biasa kita kenal dengan Ilmu Badi'. Retorika penyusunan kata atau biasa kita sebut dengan Ilmu Ma'any. Serta retorika metaforis yang biasa kita kenal dengan istilah Ilmu Bayan.

dalam penelitian ini, peneliti akan mengulik pidato Presiden Palestina Mahmoud Abbas pada Sidang Majelis Umum PBB ke-75 yang disampaikan secara virtual di New York, 22 September 2020. Dalam pidatonya, Mahmoud Abbas menyampaikan masalah-masalah Palestina yang sampai sekarang belum mendapat solusi yang jelas. Apalagi, pidato belai disampaikan pasca kabar pahit tentang disetujuinya normalisasi hubungan UEA dan Bahrain dengan Israel. Tujuannya jelas, yakni membentuk persepsi dan meraih simpati publik ${ }^{9}$, publik yang dimaksud disini adalah kepala negara, pejabat tinggi PBB, serta DK PBB yang hadir dalam sidang tersebut. Dalam Pidatonya, Mahmoud Abbas acapkali menggunakan bahasa Arab dengan retorika yang terkesan sangat mewakili keprihatinannya terhadap negerinya. Sebuah keunggulan tersendiri dari bahasa Arab yang memiliki ilmu retorika yang cukup kompleks

${ }^{7}$ Anwar Arifin, Komunikasi politik: paradigma, teori, aplikasi, strategi komunikasi politik Indonesia, 5793 (Balai Pustaka, 2003), 178.

${ }^{8}$ Ali Al-Jarim, Al-Balaghah Al-Wadihah: Al-Bayan Wa Al-Ma'any Wa Al-Badi' Li AlMadaris Al-Tsanawiyah (Kairo: Dar Al-Ma'arif, 1979), 1.

9 Asmara, "Strategi Kebahasaan Presiden Jokowi Dalam Menanamkan Ideologi Dan Manifesto Pemerintahan," 280. 
Muhammad Bachrul Ulum: Perifrasa dalam Retorika Presiden Mahmoud Abbas (Studi Balaghah Perspektif Politik)

untuk digunakan sebagai alat penarikan simpati publik, dan ilustrasi yang lebih gamblang.

Perjuangan Palestina di atas podium PBB bukanlah hal baru. Tahun 1974 Palestine Liberation Organization (PLO) atau Organisasi Pembebasan Palestina diberikan status pengamat oleh resolusi 3239 PBB, sehingga PLO berhak berpartisipasi dalam kegiatan dibawah naungan Majelis Umum PBB. Kemudian di bulan Juli 1977 PLO menjadi anggota penuh UN-ESCWA (United Nation Economic Social Commission for West Asia) / الإسكوا (Lajnah Al-Umam AlMuttahidah Al-Iqtishadiyah wa Al-Ijtimaiyah Li Gharb Asia) yang berkedudukan di Beirut, Lebanon. Kemudian, Tahun 1988 Majelis PBB memutuskan bahwa PLO berhak menjalin komunikasi secara resmi dengan PBB. Tanggal 9 Februari 1989, DK PBB mempertimbangkan permintaan Observer Palestina untuk bergabung dalam forum debat DK PBB. Lalu, pada tanggal 7 Juli 1998 Resolusi PBB mengizinkan Palestina berpartisipasi dalam kerja PBB, padahal saat itu status Palestina masih entitas pengamat. Hingga akhirnya tahun 2012 melalui Sidang Majelis Umum PBB tahun 2012, diadakan voting untuk peningkatan status Palestina, dan menghasilkan Palestina sebagai Negara pengamat nonanggota.

Nasution menyatakan bahasa merupakan kekuasaan dan sangat berperan dalam mencapai tujuan nasional maupun internasional ${ }^{10}$. Sehingga bahasa adalah unsur yang harus sangat dipertimbangkan sebagai "senjata" yang maksimal dalam setiap penggunaannya. Bahasa telah mengepakkan sayapnya, dari sebuah alat untuk melakukan komunikasi menjadi alat untuk

10 Zahri Nasution, "Bahasa Sebagai Alat Komunikasi Politik Dalam Rangka Mempertahankan Kekuasaan," Sodality: Jurnal Sosiologi Pedesaan 1, no. 3 (11 Desember 2007): 462, https://doi.org/10.22500/sodality.v1i3.5897. 
Muhammad Bachrul Ulum: Perifrasa dalam Retorika Presiden Mahmoud Abbas (Studi Balaghah Perspektif Politik)

menyebarkan ideologi, terutama dalam bidang politik ${ }^{11}$. Hal ini disebabkan karena kampanye politik mayoritas bersifat verbal dan penuh akan orasi dan pidato. Sehingga sarana paling efektif menyampaikan ekspreis politik adalah dengan strategi kebahasaan yang pas. Apalagi seperti yang kita ketahui bersama bahwa sejarah mencatat bahwa bangsa Arab Jahiliyah telah mencapai tingkatan tertinggi dalam balaghah dan diksi ${ }^{12}$, hal itu kemudian melekat pada segala aktivitas kebahasaan orang Arab, termasuk cuitan politiknya.

Oleh karena itu, Peneliti tertarik untuk membedah sisi retoris Mahmoud Abbas tanpa mengabaikan sisi politis yang sedang beliau bawakan di atas podium. Maka penelitian ini akan menganalisis unsur - unsur retorika yang ada dalam pidato beliau, dan mencari tujuan politik dibalik unsur tersebut.

\section{Retorika Politik}

Aristoteles, Bapak retorika dunia membagi Retorika menjadi 3 macam. Yakni: Pertama, Retorika Deliberatif yang digunakan untuk memberikan pengaruh pada publik dalam kebijakan pemerintah. Kedua, Retorika Forensik yang digunakan dalam proses pengadilan. Ketiga, Retorika Demonstratif yang digunakan untuk mengembangkan wacana ${ }^{13}$. Tiga ragam retorika ini, selama dijalankan secara sempurna akan menciptakan daya persuasi yang sangat kuat ${ }^{14}$.

11 Ahmad Mubaligh, "Relasi Bahasa Dan Ideologi," LiNGUA: Jurnal Ilmu Bahasa Dan Sastra 5, no. 2 (2010): 118, https://doi.org/10.18860/ling.v5i2.622.

12 Ach Thabrani, "NADZAM DALAM I'JAZ AL QURAN MENURUT ABDUL QAHIR AL JURJANI," Al Mi'yar: Jurnal Ilmiah Pembelajaran Bahasa Arab dan Kebahasaaraban 1, no. 1 (22 April 2018): 1, https://doi.org/10.35931/am.v1i1.80.

${ }^{13}$ Arifin, Komunikasi politik, 30.

${ }^{14}$ Sung-Byung Yang dkk., "The application of Aristotle's rhetorical theory to the sharing economy: an empirical study of Airbnb," Journal of Travel \& Tourism Marketing 35, no. 7 (2 September 2018): 4, https://doi.org/10.1080/10548408.2018.1455622. 
Muhammad Bachrul Ulum: Perifrasa dalam Retorika Presiden Mahmoud Abbas (Studi Balaghah Perspektif Politik)

Retorika dalam dunia Arab sendiri sudah ada sejak zaman Pra-Islam, setidaknya menurut pelacakan Syauqi Dhaif. Hal tersebut dibuktikan dengan diabadikannya fenomena tersebut dalam Al-Quran. Bahwa bangsa Arab adalah bangsa yang sangat kuat dalam adu argumen dan perdebatan ${ }^{15}$. Hal itulah yang menyebabkan Al-Quran turun sebagai mukjizat literasi yang sangat agung. Ukuran sebuah ungkapan bisa dikatakan retorik menurut Dr. Mazin AlMubarak adalah seakan - akan pemikiran dari seseorang dapat ditranfer kepada lawan bicara dengan mimik dan ilustrasi yang sempurna ${ }^{16}$.

Dalam dunia Retorika Arab, Abdul Qahir Al-Jurjani dikenal sebagai ulama yang punya kontribusi besar terhadap ilmu balaghah sepanjang sejarah $^{17} .2$ masterpiece beliau hingga kini dianggap sebagai kitab suci dalam ilmu balaghah, yakni Dalail Al-I'jaz dan Asrar Al-Balaghah. Dalam Dalail Al-I'jaz, Abdul Qahir mengajukan konsep Ilmu Bayan yang terdiri atas 4 komponen besar, yakni Majaz, Isti'arah, Kinayah, dan Tasybih. Serta konsep Ilmu Ma'any yang disebut dengan istilah An-nadzm. Sedangkan dalam Asrar Al-Balaghah, Abdul Qahir menjelaskan soal 2 komponen Ilmu Badi', yakni Al-Muhassinat AlLafdziyah yang terdiri dari Jinas dan Saja'.

Retorika Politik adalah seni mengkonsep argumentasi dalam pengerjaan naskah pidato. Retorika pada awalnya adalah seni berdebat, sifatnya khusus dan tertutup. Yang dipelajari adalah bagaimana menghadapi satu orang dengan segala kepribadian dan strateginya. Seni ini kemudian berkembang menjadi seni komunikasi 1 arah, antara seorang pembicara (Speaker) dengan pendengar umum (audiens). Dengan demikian, retorika kemudian dikelola menjadi sebuah

\footnotetext{
${ }^{15}$ Dhaif Syauqi, Al-Balaghah: Tathawwur Wa Tarikh (Dar Al-Ma'arif, 1965), 1.

${ }^{16}$ Muhammed Nejjar, “At-Tathawwur Al-Balaghy Min Al-'Ashr Al-Jahili Hatta 'Ashr Abd Al-Qahir Al-Jurjani," Kilis 7 Aralı Üniversitesi Ilahiyat Fakültesi Dergisi 7, no. 2 (t.t.): 1216.

${ }^{17}$ Syauqi, Al-Balaghah, 160.
} 
Muhammad Bachrul Ulum: Perifrasa dalam Retorika Presiden Mahmoud Abbas (Studi Balaghah Perspektif Politik)

disiplin ilmu tersendiri ${ }^{18}$. Ketika seorang politisi melakukan aktivitas yang berkaitan dengan bahasa, baik secara verbal maupun tertulis, ia kemungkinan melakukannya dengan tujuan - tujuan berikut: Pertama, Mengajak para pendukungnya untuk meningkatkan loyalitas, bahkan menambah massa pendukung. Kedua, untuk membuat pendukung lawan politik ragu akan pilihannya. Atau ketiga, mengajak orang untuk menggunakan politik secara umum, atau etika sosial agar orang mau menarik dukungan atas kebijakan yang sedang berlaku. Ketiganya adalah potensi yang mungkin terjadi, pasca seorang politisi melakukan aktivitas yang berkaitan dengan bahasa ${ }^{19}$.

\section{Perifrasa}

Salah satu metode retorika yang sering digunakan dalam sebuah pidato politik adalah ungkapan Perifrasa. Perifrasa adalah majas yang menggunakan ungkapan yang lebih panjang sebagai ganti ungkapan yang pendek ${ }^{20}$. atau dalam bahasa Arab biasa disebut dengan Ithnab. Dalam dispilin Balaghah, Ithnab masuk pada sub Ilmu Ma'any. Ahmad Al-Hasyimi menjelaskan bahwa Ithnab adalah penambahan lafadz terhadap makna yang sama karena tujuan tertentu ${ }^{21}$.

Dalam bahasa Arab, Ithnab terbagi menjadi 7 format $^{22}$ : Pertama, Dzikr Al-Khas Ba'da Al-'Am, yakni Penyebutan kata khusus setelah kata general.

${ }^{18}$ Gita Savitri, "Konstruksi Retorika Politik dalam Restorasi Citra: Analisis Pernyataan Pers Boediono dalam Kasus Bank Century,” Jakarta: Universitas Airlangga, 2014, 33.

19 Gunta Rozina dan İndra Karapetjana, "The Use of Language in Political Rhetoric: Linguistic Manipulation," Süleyman Demirel Üniversitesi Fen-Edebiyat Fakültesi Sosyal Bilimler Dergisi 2009, no. 19 (1 April 2009): 114.

20 "Perifrasa," dalam Wikipedia bahasa Indonesia, ensiklopedia bebas, 14 November 2016, https://id.wikipedia.org/w/index.php?title=Perifrasa\&oldid=12044689.

${ }^{21}$ Ahmad Al-Hasyimi, Jawahir Al-Adab : Fi Al-Ma'any Wa Al-Bayan Wa Al-Badi' (Beirut: Al-Maktabah Al-'Ashriyah, 1999), 201.

22 Al-Jarim Ali, “Al-Balaghah Al-Wadihah,” 2017, 250. 
Muhammad Bachrul Ulum: Perifrasa dalam Retorika Presiden Mahmoud Abbas (Studi Balaghah Perspektif Politik)

Penyebutan kata general sebenarnya sudah cukup untuk memahamkan lawan bicara, namun disebutkan kata yang lebih khusus setelahnya. Seakan - akan 2 kata tersebut memiliki makna yang bebeda, padahal sama ${ }^{23}$. Fungsi format Ithnab ini adalah sebagai penekanan dan tanda keunggulan kata khusus yang lebih eksklusif dibanding kata yang general.

Kedua, Dzikr Al-'Am Ba'da Al-Khas. Yakni penyebutan kata general setelah kata yang lebih khusus. Fungsi dari format Ithnab ini adalah univeralitas setiap individu yang termasuk dalam kata general, sedangkan kata yang khuusus sebagai pusat perhatian ${ }^{24}$.

Ketiga, Al-Idah ba'da Al-Ibham, yakni memunculkan dikotomisasi makna dari 2 frasa, satu frasa bersifat global, sedangkan frasa yang lain bersifat rinci. Frasa pertama biasanya merupakan isim yang bersifat umum, sedangkan frasa kedua adalah kalimat yang menjelaskan frasa pertama. Fungsi Ithnab dalam format ini, adalah untuk mengendalikan pikiran pembaca terhadap sebuah definisi, mempertebal sebuah penjelasan, dan penguasaanya terhadap konsepnya ${ }^{25}$.

Keempat, Al-Tikrar, yakni pengulangan kata sebanyak 2 kali / lebih banyak kalimat yang sama dengan tujuan tertentu. Fungsi Ithnab dalam format ini ada banyak sekali. Sebagai bentuk Penegasan, Pemisah kalimat yang panjang, proses penguasaan, keinginan yang besar untuk meminta maaf, keinginan yang besar agar nasehatnya diterima, menandaskan sasaran bicara, menikmati penyebutan, arahan terhadap jalan yang sama.

${ }^{23}$ Jalaluddin Al-Qazwayni, Al-Idah Fi 'Ulum Al-Balaghah (Damaskus: Dar Al-Fikr Al'Araby, 2000), 153.

${ }^{24}$ Al-Hasyimi, Jawahir Al-Adab : Fi Al-Ma'any Wa Al-Bayan Wa Al-Badi', 202.

${ }^{25}$ Al-Hasyimi, 202. 
Muhammad Bachrul Ulum: Perifrasa dalam Retorika Presiden Mahmoud Abbas (Studi Balaghah Perspektif Politik)

Kelima, Al-I'tirad, atau kata sisipan. Yaitu menyisipkan kata-kata di tengah susunan kalimat atau dua kalimat yang bersambung di mana sisipan tersebut tidak memiliki kedudukan dalam I'rab. Fungsinya adalah untuk mendo'akan, mengingatkan, mengukuhkan, memuji, memohon, dan menjelaskan

Keenam, At-Tadzyil, yaitu mengikutkan kalimat pada kalimat lainnya, padahal kalimat lainnya yang mengikutinya itu mencakup makna yang terkandung dalam kalimat yang diikutinya itu ${ }^{26}$. Ada 2 jenis At-Tadzyil, yang pertama adalah At-Tadzyil Al-Matsali yakni kalimat kedua memiliki makna yang sama persis dengan kalimat pertama, hanya berbeda stilistika penyampaian. Yang kedua adalah At-Tadzyil Ghairu Al-Matsali yakni kalimat kedua merupakan bagian dari kalimat pertama, berhubungan namun berbeda dalam makna.

Ketujuh, Al-Ihtiras. Yaitu mempetegas penjelasan sebuah kata, karena khawatir akan peluang celaan terhadap pembicara atas kata tersebut. Penambahan penjelasan disini berfungsi untuk menghindarkan pendengar dari kemungkinan ambiguitas kata, sehingga menimbulkan kesalah pahaman.

\section{Metodologi}

Metode yang digunakan dalam penelitiasn ini adalah deskriptif kualitatif dengan model analisis isi (content analysis), yakni dengan analisis yang dilakukan pasca pendokumentasian data yang diambil dari korpus data ${ }^{27}$. Korpus data yang digunakan adalah rekaman pidato Presiden Mahmoud Abbas

${ }^{26}$ Al-Jarim, Al-Balaghah Al-Wadihah, 250.

'ضرب، Muhamad Hamdani, "IMPLIKASI PERUBAHAN DERIVASI DAN MAKNA DALAM AL-QURAN TERHADAP TERJEMAHNYA,” Al Mi'yar: Jurnal Ilmiah Pembelajaran Bahasa Arab Dan Kebahasaaraban 1, no. 2 (20 Oktober 2018): 75, https://doi.org/10.35931/am.v1i2.39. 
Muhammad Bachrul Ulum: Perifrasa dalam Retorika Presiden Mahmoud Abbas (Studi Balaghah Perspektif Politik)

dalam Sidang Majelis Umum Perserikatan Bangsa-Bangsa (PBB) ke-75 yang digelar secara virtual dari New York, tanggal 22-29 September 2020 melalui kanal Youtube RT Arabic ${ }^{28}$. Peneliti melakukan transkripsi terhadap video, dan menemukan beberapa kalimat yang terindikasi mengandung unsur ungkapan Perifrasa/Ithnab. Setelah dilakukan pengelompokan berdasarkan format Perifrasa yang digunakan, peneliti mengulik Faidah/Fungsi penggunaan perifrasa tersebut dari sudut pandang politik dengan data-data yang kredibel dan fakta yang terjadi.

\section{Pembahasan}

Dalam pidato kenegaraannya yang disampaikan di Sidang Majelis Umum PBB pada tanggal 22 September 2020. Mahmoud Abbas menyampaikan pidatonya dalam bahasa Arab, dan banyak menggunakan gaya perifrasa dalam pidatonya. Penggunaan gaya bahasa tersebut tidak lepas dari tujuan politisnya sebagai Presiden yang sedang memperjuangkan rakyatnya di hadapan para petinggi organisasi antar - Negara ini. Berikut adalah gaya perifrasa yang ditemukan peneliti dalam pidato Presiden Mahmoud Abbas:

a. Dzikr Al-Khas ba'da Al-'Am

Pertama, terletak pada kalimat:

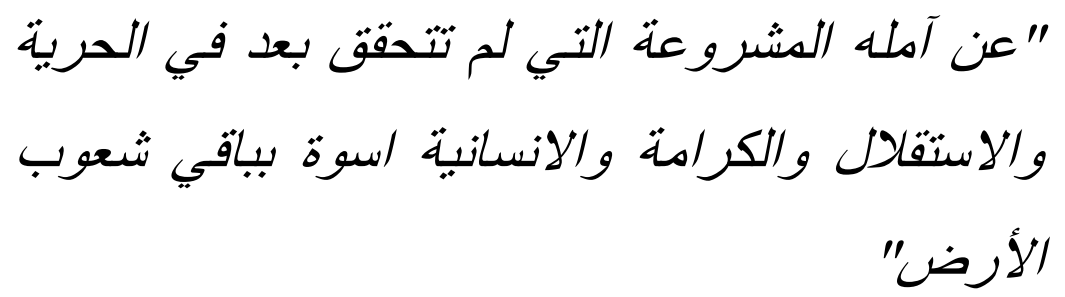

${ }^{28}$ RT Arabic, Kalimat Ar-Rais Al-Filistiny Mahmoud Abbas Amama Al-Jam'iyyah Al$\begin{array}{lcc}\text { 'Ammah } \quad l i & \text { Al-Umam } \\ \text { https://www.youtube.com/watch?v=DTUHXkR4Djs\&t=2s. }\end{array}$ Al-Muttahidah, 2020 , 
Muhammad Bachrul Ulum: Perifrasa dalam Retorika Presiden Mahmoud Abbas (Studi Balaghah Perspektif Politik)

Dalam kalimat diatas, yang menempati posisi Al-'Am adalah lafadz (impian bangsa Palestina). Dan Al-Khas adalah الحرية والاستقلال و الكرامة والإنسانية (Kebebasan, Kemerdekaan, Kehormatan, dan Kemanusiaan). Mahmoud Abbas merasa bahwa impian - impian Palestina yang selama ini mereka suarakan tidak mendapat respon yang cukup besar, sehingga beliau merasa perlu memberikan penekana terhadap hal - hal yang lebih spesifik. Kebebasan, Kemerdekaan dan Kehormatan Palestina telah direbut oleh Israel sejak diumumkannya kemerdekaan Israel tahun 1948, hari itu sekaligus menandai dimulainya konflik Palestina-Israel dan hilangnya hak - hak bangsa Palestina ${ }^{29}$.

Kedua, terletak pada kalimat:

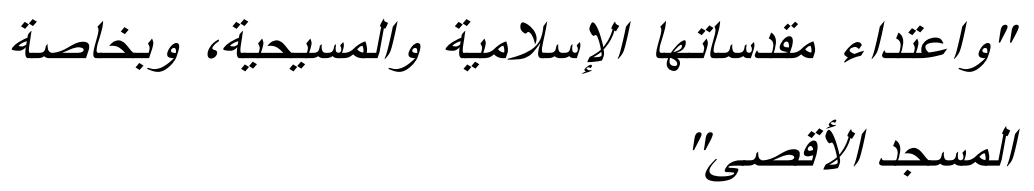

Dalam kalimat diatas, yang menempati posisi Al-'Am adalah lafadz مقدساتها (Kesucian Yerusalem dari sisi Islam maupun Kristen). Dan AlKhas adalah المسجد الأقصى (Masjid Al-Aqsa). Menurut Abbas dan rakyat Palestina, Al-Aqsa merupakan wilayah eksklusif yang setidak-tidaknya harus aman dari serangan apapun. Karena Al-Aqsa merupakan tempat suci 3 agama dunia. Hamas (Harakat Al-Muqawamah Al-Islamiyah) Sebagai organisasi garda terdepan pembela Palestina memperingatkan Israel, bahwa penyerangan terhadap Al-Aqsa akan memicu peperangan besar. Ariel Sharon, seorang Politisi Israel pada tanggal 28 Speptember 2000 membawa pasukan Israel ke Al-Aqsa

${ }^{29}$ Masyrofah Masyrofah, "Fakta Perjanjian Damai Dan Hubungan Diplomatik Negara Timur Tengah Dalam Proses Perdamaian Konflik Israel-Palestina Pasca Kemerdekaan Palestina," SALAM: Jurnal Sosial Dan Budaya Syar-i 2, no. 1 (2015): 82, https://doi.org/10.15408/sjsbs.v2i1.2243. 
Muhammad Bachrul Ulum: Perifrasa dalam Retorika Presiden Mahmoud Abbas (Studi Balaghah Perspektif Politik)

dan menyatakan pendudukannya terhadap Al-Aqsa. Dan ini dinilai sebagai tindakan semena - mena yang tak bisa dimaafkan ${ }^{30}$.

Ketiga, Pada kalimat :

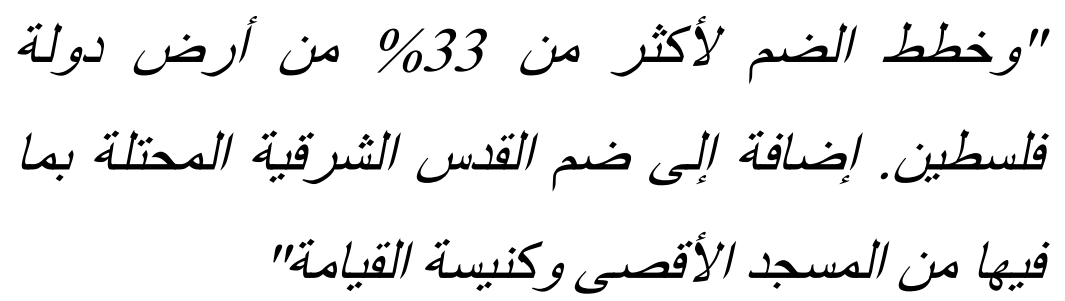

Pada pernyataan diatas, kata yang Al-'Am adalah 33. (33\% dari wilayah Negara Palestina). Kemudian Mahmoud menuturkan kalimat القس الثرقية المحتلة بما فيها من المسجد الأقصى وكميسة القيامة yang lebih spesifik, yakni (Yerusalem Timur yang terjajah, lokasi dari Masjid Al-Aqsa dan Gereja Makam Kudus). Dalam pernyataannya, Mahmoud menyayangkan tindakan Israel dan Amerika Serikat yang berupaya memindahkan Ibukota Israel dari Tel Aviv ke Yerusalem Timur tahun 2017. Palestina melalui OKI menolak pernyataan unilateral Presiden AS Donald Trump yang akan memindahkan Kedutaan besar AS untuk Israel dari Tel Aviv Ke Yerusalem Timur. Penolakan tersebut disampaikan melalui gelaran Sidang Darurat OKI tanggal 13 Desember 2017 di Istanbul ${ }^{31}$.

\section{b. Al-Idhah Ba'da Al-Ibham}

${ }^{30}$ Mahlil Idatul Humairah dan Abdul Fadhil, "Gerakan Intifadhah dan Kemunculan Hamas (1987-1993),” PERIODE: Jurnal Sejarah dan Pendidikan Sejarah 1, no. 1 (2019): 7.

${ }^{31}$ Naashihul Umam, "Penguasan Wilayah Palestina Oleh Israel Dalam Perspektif Hukum Internasional," Dinamika: Jurnal Ilmiah Ilmu Hukum 25, no. 13 (29 Juli 2019): 2, http://www.riset.unisma.ac.id/index.php/jdh/article/view/4144. 
Pertama, pada kalimat:

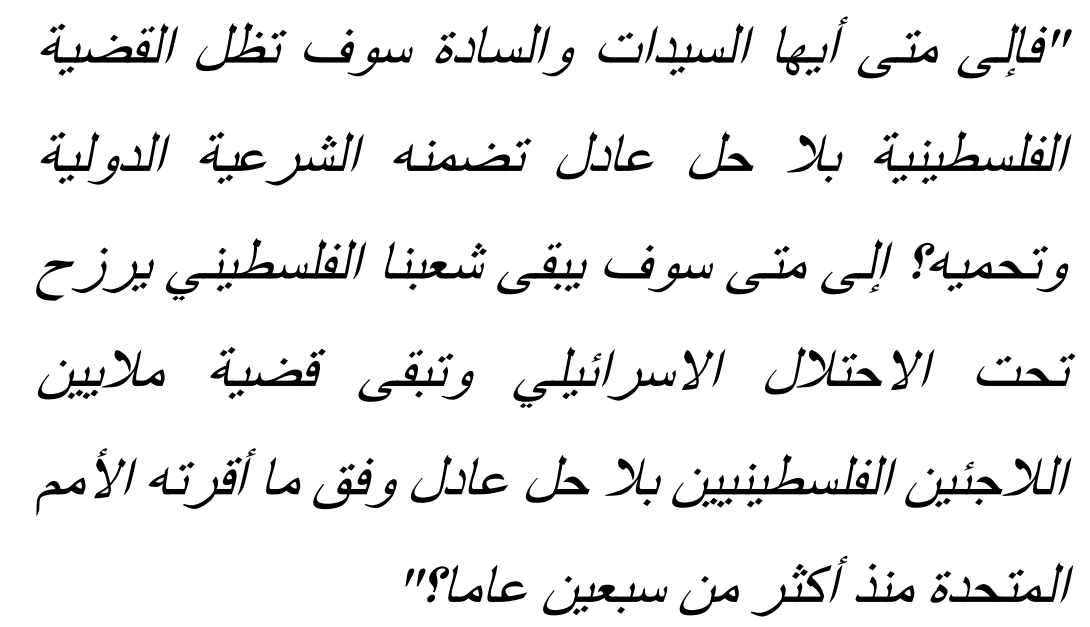

Kata yang berhukum Ibham adalah القضية الفلسطينية (Problematika Palestina) yang kemudian dijelaskan oleh Mahmoud Abbas, dengan kalimat yang lebih gamblang pada statement keduanya يقى شعبنا الفلسطيني يرزح تحت الاحتلال الاسر ائيلي وتبقى قضية ملايين اللاجئين الفلسطينيين بلا حل عادل وفق ما أقرته الأمم المتحدة منذ أكثر من (Bangsa kita, Palestina terbengkalai dalam penderitaan dibawah penjajahan Israel, dan kasus-kasus jutaan pengungsi Palestina terbengkalai tanpa solusi yang adil sesuai mandat PBB sejak lebih dari 70 tahun). Dalam ungkapan perifrasanya tersebut, Mahmoud merasa perlu menjelaskan apay yang dimaksud Problematika Palestina, karena kata-kata tersebut terlalu umum dan bisa dimulti tafsirkan. Mahmoud juga menyebutkan secara eksplisit kata "Mandat PBB" dalam forum tersebut, sebagai bentuk protes terhadap kebijakankebijakan PBB yang selama ini dinilai tidak punyai nilai praktis dalam pembebasan palestina. Sejak DK PBB no.388 tahun 1967 sampai DK PBB no.1515 tentang resolusi Israel-Palestina, hingga pembentukan Two-State 
Muhammad Bachrul Ulum: Perifrasa dalam Retorika Presiden Mahmoud Abbas (Studi Balaghah Perspektif Politik)

Solution melalui Konferensi Madrid tahun 1991 hingga Perjanjian Perdamaian tahun 2013-2014 selalu mengalami kegagalan ${ }^{32}$.

Kedua, pada kalimat:

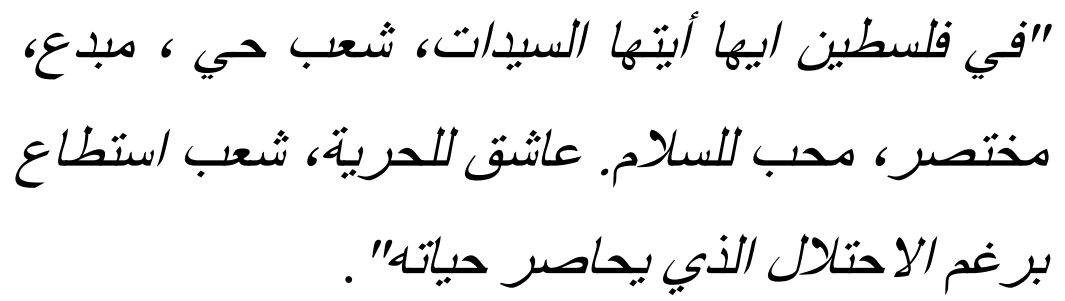

Kata yang dimaksud Ibham dalam kalimat ini adalah kata شعب (bangsa), dalam hal ini adalah bangsa Palestina. Mahmoud memberikan gambarang, bahwa Palestina bukan sekedar bangsa yang "hidup", penuh kreatifitas, sederhana, dan mencintai perdamaian. Palestina juga merupakan bangsa yang استطاع برغم الاحتلال الذي يحاصر حياته (mampu hidup, walaupun dibawah penjajahan yang menyengsarakan kehidupan mereka). Frasa tersebut, sebenarnya sudah dijelaskan dalam kata عاشق للسلام (cinta damai). Mahmoud merasa perlu menekankan kembali hal ini, karena begitulah sifat seorang yang cinta damai selalu ditindas. Rencana Penindasan ini sudah berlangsung sejak lama, bahkan jauh sebelum konflik Israel-Palestina muncul. Tahun 1887, berdiri sebuah organisasi zionis dunia (World Zionist Organization) yang salah satu dari ke-4 agendanya adalah melakukan promosi, mengikat kesesuaian, tentang penjajahan Palestina melalui sistem pertanian dan pekerja Industri Yahudi ${ }^{33}$. Israel menghalalkan segala cara demi tercapainya tujuan-tujuan entitasnya.

c. At-Tikrar

${ }^{32}$ Ichlasul Amal, "The Future of Israel-Palestinian Conflict: Either One State or Two?," Global Strategis 14, no. 1 (2020): 67.

${ }^{33}$ Misri A. Muchsin, "PALESTINA DAN ISRAEL: Sejarah, Konflik dan Masa Depan," MIQOT: Jurnal Ilmu-ilmu Keislaman 39, no. 2 (2015): 399. 
Pertama, terletak pada kalimat :

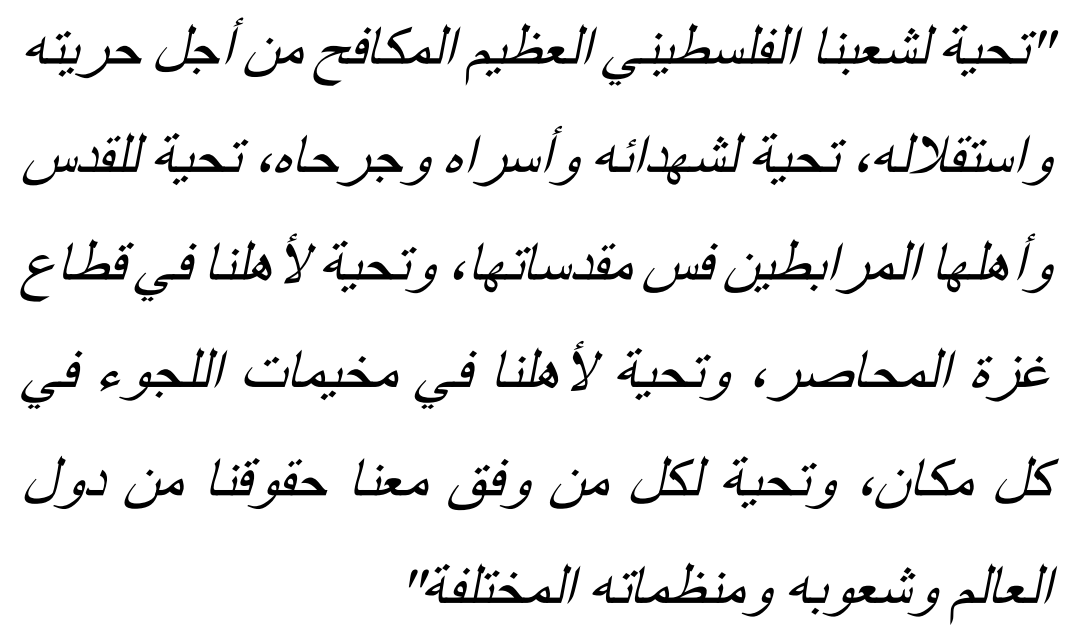

Kata yang diulang - ulang oleh Mahmoud adalah تحية (salam). Di satu sisi, dalam pengucapannya ada unsur Taladzudz (menikmati), sebagai bentuk rasa terima kasih Mahmoud terhadap segala pihak yang telah membantu dalam proses pembebasan Palestina. Usaha yang telah dilakukan berbagai pihak mulai dari perang besar Arab-Israel tahun 1948, Six Day War tahun 1967, hingga saat ini adalah sesuatu yang sangat disyukuri oleh Mahmoud, terlepas dari belum tercapainya perjuangan Palestina. Rasa terima kasih yang diungkapkan Mahmoud kali ini agak berbeda dengan yang disampaikan pada Sidang Darurat OKI tahun 2017 di Turki. Dimana Mahmoud menyatakan terima kasihnya secara langsung dengan kata.

Kedua, pada kalimat :

${ }^{34}$ Hasrul Azmi, "Tindak Tutur Ekspresif Pidato Presiden Palestina Mahmoud Abbas dalam KTT OKI 2017 (Kajian Pragmatik),” 2018, 6. 


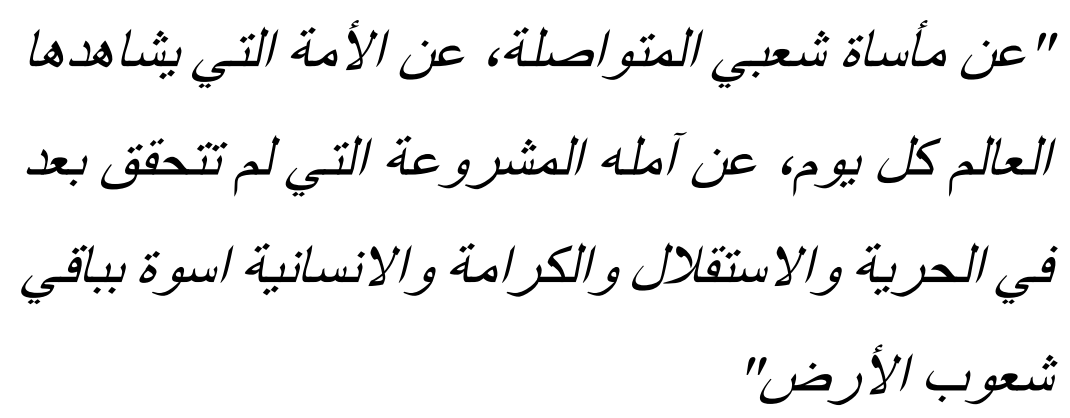

Pengulangan yang terjadi disini adalah pengulangan kata عن (tentang) terhadap beberapa hal yang selalu jadi pertanyaan Mahmoud terhadap PBB. Pengulangan disini adalah bentuk keinginan Mahmoud agar tuturannya didengarkan dengan seksama oleh para petinggi PBB. Sebagaimana keluhannya pada beberapa kalimat sebelumnya, bahwa pertanyaan ini selalu diulang oleh Mahmoud dalam setiap pidatonya.

Keempat, Pada kalimat:

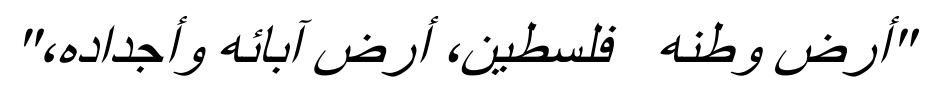

Pengulangan kata أرض (tanah air) merupakan bentuk penegasan terhadap apa yang sedang diperjuangkan oleh rakyat Palestina. Sengketa tanah / wilayah adalah poros permasalahan Israel-Palestina. Tahun 1947 Majelis Umum PBB mengeluarkan resolusi nomor 181 tentang rancangan Pembagian Wilayah Israel-Palestina. Dalam resolusi tersebut, Palestina dipaksa memberikan 56\% wilayahnya, dan sisanya 44\% menjadi milik Palestina. Angka 56\% tersebut selain menurut bangsa Arab dianggap tidak adil, juga memasukkan wilayah Al-Quds (Yerusalem) dan Betlehem sebagai wilayah 
Muhammad Bachrul Ulum: Perifrasa dalam Retorika Presiden Mahmoud Abbas (Studi Balaghah Perspektif Politik)

dalam kendali internasional ${ }^{35}$. Hal inilah yang akhirnya menginisasi Perang Arab-Israel tahun 1948.

d. Al-I'tiradh

Terdapat pada kalimat:

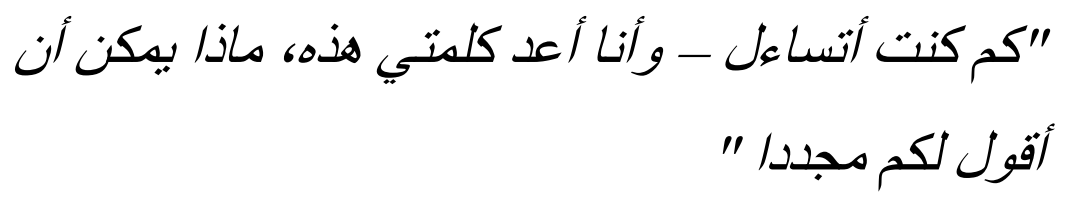

و أنا أعد كلمني Kalimat I'tiradh atau Al-Jumlah Al-Mu'taridah tertetak pada kalimat هذه. Kalimat tersebut tidak mempunyai posisi I'rab apapun dalam kalimat tersebut, karena hanya merupakan penjelasan atas kalimat sebelumnya. Mahmoud merasa perlu menyampaikan kata tersebut sebagai ungkapan rasa "letihnya" terhadap permintaannya kepada segala pihak untuk menyelesaikan konflik Palestina-Israel.

e. At-Tadzyil

Pertama, terletak pada kalimat:

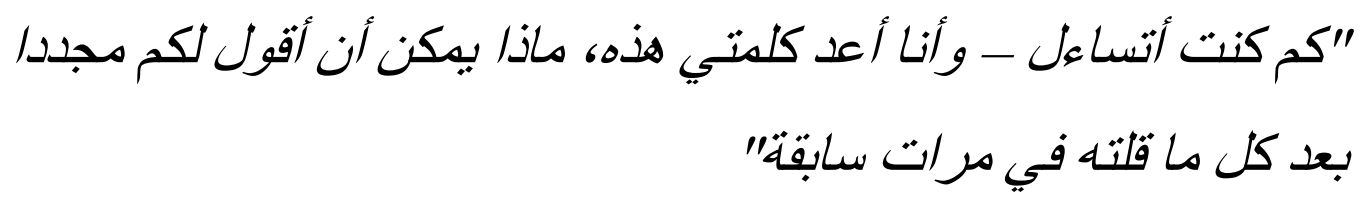

Dalam pernyataan tersebut, terdapat Al-Tadyil Al-Matsali. Kalimat utamanya adalah كم كنت اتساءل (Sudah berapa kali saya mempertanyakan). Kemudian ماذا يمكن أن أقول لكم Mahmoud melanjutkan pernyataannya dengan anak kalimat Internasional," 3 .

35 Umam, "Penguasan Wilayah Palestina Oleh Israel Dalam Perspektif Hukum 230 
Muhammad Bachrul Ulum: Perifrasa dalam Retorika Presiden Mahmoud Abbas (Studi Balaghah Perspektif Politik)

(Apa yang mungkin akan saya katakana pada hadirin sekalian lagi dan lagi, setelah sudah saya katakana di kesempatan - kesempatan yang telah lalu). Anak kalimat tersebut memiliki makna yang sebenarnya sama dengan kalimat induknya. Tujuan penggunaan Tadzyil disini adalah penandasan akan begitu letihnya Mahmoud sebagai wakil rakyat Palestina memperjuangkan nasib rakyatnya di depan podium PBB sebagai organisasi antar-negara terbesar di seluruh dunia. Pencapaian terbesar Mahmoud sebagai Presiden Palestina adalah, akhirnya dalam pidatonya di Sidang Majelis Umum PBB tahun 2012, Mahmoud berhasil mengubah status Palestina dari Entitas Pemantau nonAnggota menjadi Negara Pemantau Non-Anggota ${ }^{36}$.

\section{Simpulan}

Pidato Presiden Mahmoud Abbas dalam Sidang Majelis Umum PBB ke 75 menunjukkan bahwa Ilmu Bahasa, khususnya retorika sangat penting dalam kepentingan Politik. Seorang politisi harus mengetahui strategi beretorika dan faham unsur - unsur kebahasaan sebagai strategi untuk mencapai kepentingan politiknya. Dalam hal ini, Mahmoud Abbas dan retorika politiknya telah menunjukkan kepada kita betapa pentingnya menyusun strategi dalam pidato, termasuk memasukkan Perifrasa sebagai salah satu unsur yang cukup krusial dalam tata bahasa Pidato. Terlepas dari direspon secara bagaimana Pidato Mahmoud Abbas oleh para petinggi PBB, Mahmoud Abbas telah berhasil meluncurkan Ideologi Politiknya kepada mereka lewat strategi penyusunan

${ }^{36}$ Windy Widya Utami, Arif Arif, dan Jelly Leviza, "Perubahan Entitas Palestina oleh Pbb dan Eksistensinya sebagai Negara Pemantau Non Anggota," Sumatra Journal of International Law 1, no. 3 (2013): 4. 
Muhammad Bachrul Ulum: Perifrasa dalam Retorika Presiden Mahmoud Abbas (Studi Balaghah Perspektif Politik)

perifrasa dalam Pidatonya, dan menunjukkan bahwa ada pesan di setiap detail bahasa yang keluar dari mulut seseorang politisi.

\section{Daftar Pustaka}

Al-Hasyimi, Ahmad. Jawahir Al-Adab : Fi Al-Ma'any Wa Al-Bayan Wa Al-Badi'. Beirut: Al-Maktabah Al-'Ashriyah, 1999.

Ali, Al-Jarim. "Al-Balaghah Al-Wadihah," 2017.

Al-Jarim, Ali. Al-Balaghah Al-Wadihah : Al-Bayan Wa Al-Ma'any Wa Al-Badi' Li Al-Madaris Al-Tsanawiyah. Kairo: Dar Al-Ma'arif, 1979.

Al-Qazwayni, Jalaluddin. Al-Idah Fi 'Ulum Al-Balaghah. Damaskus: Dar Al-Fikr Al-'Araby, 2000.

Amal, Ichlasul. "The Future of Israel-Palestinian Conflict: Either One State or Two?" Global Strategis 14, no. 1 (2020): 63-76.

Arifin, Anwar. Komunikasi politik: paradigma, teori, aplikasi, strategi komunikasi politik Indonesia. 5793. Balai Pustaka, 2003.

Asmara, Rangga. "Strategi Kebahasaan Presiden Jokowi Dalam Menanamkan Ideologi Dan Manifesto Pemerintahan." Litera 15, no. 2 (2016): 379-88. https://doi.org/10.21831/ltr.v15i2.11836.

Asror, Abdul Ghoni. "Bahasa Pencitraan Dalam Iklan Kampanye Pilkada Kabupaten Bojonegoro." Magistra 26, no. 92 (2015): 24.

Azmi, Hasrul. "Tindak Tutur Ekspresif Pidato Presiden Palestina Mahmoud Abbas dalam KTT OKI 2017 (Kajian Pragmatik)," 2018.

Falach, Ghulam, dan Ridhatullah Assya'bani. "Telaah Semiotik Pendidikan Nasionalisme Dalam Puisi 'Risālah Min Al Mu'taqil' Karya Sāmih AlQāsim." Al Mi'yar: Jurnal Ilmiah Pembelajaran Bahasa Arab Dan Kebahasaaraban 3, no. 2 (10 Oktober 2020): 231-50. https://doi.org/10.35931/am.v3i2.341. 
Muhammad Bachrul Ulum: Perifrasa dalam Retorika Presiden Mahmoud Abbas (Studi Balaghah Perspektif Politik)

Hamdani, Muhamad. “Implikasi Perubahan Derivasi Dan Makna 'ضرب' Dalam Al-Quran Terhadap Terjemahnya." Al Mi'yar: Jurnal Ilmiah Pembelajaran Bahasa Arab Dan Kebahasaaraban 1, no. 2 (20 Oktober 2018): 71-86. https://doi.org/10.35931/am.v1i2.39.

Humairah, Mahlil Idatul, dan Abdul Fadhil. "Gerakan Intifadhah dan Kemunculan Hamas (1987-1993)." PERIODE: Jurnal Sejarah dan Pendidikan Sejarah 1, no. 1 (2019): 1-14.

Krebs, Ronald R., dan Patrick Thaddeus Jackson. "Twisting Tongues and Twisting Arms: The Power of Political Rhetoric." European Journal of International Relations 13, no. 1 (1 Maret 2007): 35-66. https://doi.org/10.1177/1354066107074284.

Luhukay, Marsefio S. "Presiden SBY dan Politik Pencitraan: Analisis Teks Pidato Presiden SBY dengan Pendekatan Retorika Aristoteles." Scriptura 1, no. 2 (2007).

Masyrofah, Masyrofah. "Fakta Perjanjian Damai Dan Hubungan Diplomatik Negara Timur Tengah Dalam Proses Perdamaian Konflik Israel-Palestina Pasca Kemerdekaan Palestina." SALAM: Jurnal Sosial Dan Budaya Syar-i 2, no. 1 (2015). https://doi.org/10.15408/sjsbs.v2i1.2243.

Mubaligh, Ahmad. "Relasi Bahasa Dan Ideologi." LiNGUA: Jurnal Ilmu Bahasa Dan Sastra 5, no. 2 (2010). https://doi.org/10.18860/ling.v5i2.622.

Muchsin, Misri A. "PALESTINA DAN ISRAEL: Sejarah, Konflik dan Masa Depan.” MIQOT: Jurnal Ilmu-ilmu Keislaman 39, no. 2 (2015).

Nasution, Zahri. "Bahasa Sebagai Alat Komunikasi Politik Dalam Rangka Mempertahankan Kekuasaan." Sodality: Jurnal Sosiologi Pedesaan 1, no. 3 (11 Desember 2007). https://doi.org/10.22500/sodality.v1i3.5897.

Nejjar, Muhammed. "At-Tathawwur Al-Balaghy Min Al-'Ashr Al-Jahili Hatta 'Ashr Abd Al-Qahir Al-Jurjani." Kilis 7 Arallk Üniversitesi İlahiyat Fakültesi Dergisi 7, no. 2 (t.t.): 1209-39.

"Perifrasa." Dalam Wikipedia bahasa Indonesia, ensiklopedia bebas, 14 November 2016.

https://id.wikipedia.org/w/index.php?title=Perifrasa\&oldid=12044689. 
Muhammad Bachrul Ulum: Perifrasa dalam Retorika Presiden Mahmoud Abbas (Studi Balaghah Perspektif Politik)

Rozina, Gunta, dan İndra Karapetjana. "The Use of Language in Political Rhetoric: Linguistic Manipulation." Süleyman Demirel Üniversitesi FenEdebiyat Fakültesi Sosyal Bilimler Dergisi 2009, no. 19 (1 April 2009): 11122.

RT Arabic. Kalimat Ar-Rais Al-Filistiny Mahmoud Abbas Amama Al-Jam'iyyah Al'Ammah li Al-Umam Al-Muttahidah, 2020. https://www.youtube.com/watch?v=DTUHXkR4Djs\&t=2s.

Savitri, Gita. "Konstruksi Retorika Politik dalam Restorasi Citra: Analisis Pernyataan Pers Boediono dalam Kasus Bank Century." Jakarta: Universitas Airlangga, 2014.

Syauqi, Dhaif. Al-Balaghah : Tathawwur Wa Tarikh. Dar Al-Ma'arif, 1965.

Thabrani, Ach. "NADZAM DALAM I'JAZ AL QURAN MENURUT ABDUL QAHIR AL JURJANI." Al Mi'yar: Jurnal Ilmiah Pembelajaran Bahasa Arab dan Kebahasaaraban 1, no. 1 (22 April 2018): 1-14. https://doi.org/10.35931/am.v1i1.80.

Thomas, Linda, Shan Wareing, Jason Jones, dan Joanna Thornborrow. Language, society and power: An introduction. Psychology Press, 2004.

Umam, Naashihul. "Penguasan Wilayah Palestina Oleh Israel Dalam Perspektif Hukum Internasional.” Dinamika: Jurnal Ilmiah Ilmu Hukum 25, no. 13 (29 Juli 2019). http://www.riset.unisma.ac.id/index.php/jdh/article/view/4144.

Utami, Windy Widya, Arif Arif, dan Jelly Leviza. "Perubahan Entitas Palestina oleh Pbb dan Eksistensinya sebagai Negara Pemantau Non Anggota." Sumatra Journal of International Law 1, no. 3 (2013): 14987.

Yang, Sung-Byung, Hanna Lee, Kyungmin Lee, dan Chulmo Koo. "The application of Aristotle's rhetorical theory to the sharing economy: an empirical study of Airbnb." Journal of Travel \& Tourism Marketing 35, no. 7 (2 September 2018): 938-57. https://doi.org/10.1080/10548408.2018.1455622. 